\title{
The Knowledge and Attitudes of Occupational Therapy, Physiotherapy and Speech-language Therapy Students, regarding the Speech-language Therapist's Role in the Hospital Stroke Rehabilitation Team.
}

\author{
Lisa Felsher and Eleanor Ross \\ Department of Speech Pathology and Audiology \\ University of the Witwatersrand
}

\begin{abstract}
The purpose of the present study was to survey and compare the knowledge and attitudes of final year occupational therapy, physiotherapy and speech-language therapy students, concerning the role of the speech-language therapist as a member of the stroke rehabilitation team in the hospital setting. In order to achieve this aim, a questionnaire was administered to final year students in these three disciplines, and included questions on most areas of stroke rehabilitation with which the speech-language therapist might be involved, as well as the concepts of rehabilitation and teamwork in relation to stroke rehabilitation. Results suggested a fairly good understanding of the concepts of rehabilitation and teamwork. Students appeared to have a greater understanding of those disorders following a stroke, with which the speech-language therapist is commonly involved, such as Aphasia, Dysarthria, Verbal Apraxia and Dysphagia. However, students appeared to show less understanding of those disorders post-stroke, for which the speechlanguage therapist's role is less well defined, such as Agraphia, Alexia and Amnesia. In addition, a high percentage of role duplication / overlapping in several aspects of stroke rehabilitation, such as family and social support, was found. Several implications for facilitating communication, collaboration and understanding between paramedical professions, as well as for further research are also provided.
\end{abstract}

\section{OPSOMMING}

Die doel van die huidige studie was om die kennis en houdings van finalejaarstudente in arbeids-, fisio-en spraaktaalterapie ten opsigte van die rol van die spraak-taalterapeut as lid van die beroerterehabilitasiespan in die hospitaalopset te ondersoek en te vergelyk. Om die doel te bereik, is ' $n$ vraelys deur die finalejaarstudente in die drie dissiplines voltooi en is vrae in die meeste areas van beroerterehabilitasie waarby die spraak-taalterapeut betrokke mag wees, sowel as konseptè van rehabilitasie en spanwerk in verband met beroerterehabilitasie, ingesluit. Die resultate dui op 'n redelike goeie begrip van die konsepte van spanwerk en rehabilitasie. Die studente blyk ' $n$ beter begrip te hê vir die afwykings na 'n beroerte waarby die spraak-taalterapeut dikwels betrokke is, soos afasie, disartrie, verbale apraksie en disfagie. Die studente toon egter minder begrip van die afwykings na beroerte waar die spraak-taalterapeut se rol minder duidelik gedefinieer is soos agrafie, aleksie en amnesie. Verder is 'n hoë persentasie van die funksies dupliserend of oorvleuelend bevind in 'n aantal aspekte van beroerterehabilitasie soos familiale en sosiale ondersteuning. Verskeie implikasies vir die fasilitering van kommunikasie en begrip tussen paramediese professionele personeel, sowel as vir verdere navorsing is ook verskaf.

Stroke is regarded as one of the leading causes of death and disability in all races in South Africa (Fritz \& Penn, 1992). The term "stroke" is synonymous with cerebrovascular accident (CVA), which according to the World Health Organisation (WHO), can be defined as "a sudden (acute) disturbance) of brain (cerebral) function of vascular origin, causing disability lasting more than, or death within, 24 hours" (Clifford-Rose \& Capildeo, 1981). The consequences of stroke are far ranging and include physical, communication, social, personal and economic disturbances. Apart from the medical attention stroke patients may need, they may also require nursing support, and will usually need help in recovering their physical, emotional and social functioning (Wade, Langton-Hewer, Skilbeck \& David, 1985). Thus, more often the major thrust of therapy is in teaching the patient to live in a normal environment, providing family support, social welfare assistance, psychological care, and rehabilitation of speech, movement and co-ordination (Fritz \& Penn, 1992).

Chamberlain (1989, p.311) defined rehabilitation as "a process designed to maximise a patient's physical, mental, social and vocational potential." As no single health professional can be expert in all these areas, a team of professionals is necessary for a rehabilitative programme to be effective (Stonnington \& Browne, 
1987). Dean \& Geiringer (1990, p.275) add that the ideal rehabilitation team uses an interdisciplinary approach, whereby "individual professionals from different disciplines evaluate patients according to their own speciality and contribute to a team conference for the patient." Through the synchronous endeavours of multiple specialists, rehabilitation thus attempts to identify all disturbances and their causes, attempting to reduce them, while simultaneously identifying compensating strengths (Bluestone, 1976).

The concept of team management is rapidly becoming accepted as one of the most holistic, economic and efficient means of providing a patient with the best possible care (Haller \& Sheldon, 1976; Boone, 1987). While many advantages of teamwork have been listed in the literature, such as the experience in participatory learning for team members and the provision of a comprehensive but integrated range of services for the patient (Kane, 1975; Germain, 1984; Stonnington \& Browne, 1987), several disadvantages to team practice also exist. These include a lack of knowledge about the education and expertise of other disciplines, the problem of role definition that exists among team members, and the fostering of undesirable competition or professional jealousy.

According to Penn (1992), a large proportion of people who have had a stroke, suffer from a communication disability. Hence, the speech-language therapist who specializes in communication disorders, is an integral member of the professional partnership that exists between rehabilitation specialists. "Communication is a basic function, taken for granted until it fails" (Wade et al., 1985, p.135). The three most common disorders of communication resulting from a stroke which affect speech and language are Aphasia, Dysarthria and Apraxia. Aphasia refers to "the loss or impairment of the ability to use and understand language" (Fritz \& Penn, 1992, p.203), while Dysarthria is defined as an "impairment in articulation of sounds caused by muscle weaknesses and incoordination of muscles responsible for speech and breathing" (Fritz \& Penn, 1992, p.205). In contrast, Apraxia, which is "a disorder of learned movement distinct from paralysis, weakness and incoordination, that results in a disturbance in motor-planning" (Love \& Webb, 1986, p. 275). In addition, Dysphagia which is a disorder of swallowing, occurs in approximately one third of stroke patients (Penn, 1992).

Communication disorders "often impinge upon social, emotional and financial well-being" (Simmons, 1985, p.7). As a result, "speech pathology and audiology have a closer affinity to rehabilitation medicine than any other department in a hospital" (Bluestone, 1976, p.12). Moreover, Simmons (1981) states that the speech-language therapist, who is experienced in the diagnosis and management of neuropathologies of communication, can be a major contributor to the care of the neurologically impaired patient.

According to Softley (1987), the aims of treating speech and language disorders in the stroke patient, are the restoration of an effective communication system and the readjustment of the patient and his/her family, to changes in the way they communicate. In addition Penn (1992, p.55) states that "a speech and language therapist teaches patients to communicate as fully as possible, assessing and treating problems of speech, hearing, understanding, verbal and gestural expression, and reading and writing disorders."

According to Simmons (1981), the management of the patient with a neurogenic communication disorder ideally involves a co-operative interaction between medical specialists and speech-language therapists. In addition, a variety of other professionals are extremely important in the management of patients with neurogenic communication disorders. While physiotherapists and occupational therapists improve the physical foundations for successful communication and contribute information on the integrity of sensori-motor systems, the neuropsychologist where appropriate, administers comprehensive test batteries to provide data on various aspects of intelligence and mental status (Simmons, 1981).

From the previous discussion, it would appear that the speech-language therapist has a crucial role to play in the stroke rehabilitation team. However, it would seem that there is often a lack of understanding among medical and paramedical personnel regarding the role and functions of speech and language therapy, with the result that the patients requiring such services may not always be referred to a speech-language therapist (Clifford-Rose \& Capildeo, 1981). This fact is illustrated by Milner (1989), who investigated the knowledge and attitudes of senior medical students concerning the role of the speech-language and hearing therapist in the treatment of communication disorders. She concluded that most members of the medical profession remain unaware of the critical importance of speech and hearing therapy services for individuals whose communication abilities are impaired.

Findings in this study suggested that the medical students required education concerning the profession of speech and hearing therapy, and "the assistance that speech and hearing therapists can offer as members of the health team" (p.30). Furthermore, Motona and Nowitz (1991) attempted to establish qualified physiotherapists' appropriate definitions of rehabilitation, and their yiews regarding what it encompasses. Included in a questionnaire, were questions pertaining to the composition and leadership of the rehabilitation team. The speech-language therapist was seen to be an essential member of the team, however, the extent to which he/ she is involved in the stroke rehabilitation team was not established. In a study by Waller and Murphy (1985), speech-language therapists who work in a medical setting, were requested to indicate how well other rehabilitation workers understood the role of the speech-language therapist. Approximately sixty percent of the occupational therapists, and approximately fifty percent of the physiotherapists indicated that they had a good understanding of the speech-language therapist's role, while the remaining percentage of each profession had only some or no understanding.

As a result of these research findings, it appeared to be both relevant and timely to investigate the knowledge and attitudes of final year occupational therapy and physiotherapy students towards the róle of the speech-language therapist as a member of the stroke rehabilitation team in a hospital setting, and to compare their views with those of final year speech and hearing therapy students. Since final year students represent future allied health professionals in the new South Africa, it was envisaged that a survey-type re- 
search project targeted at final year students, would provide some indication of the preparation they receive during their formal undergraduate training, in terms of stroke rehabilitation and the various professions involved in an inter-disciplinary team. Furthermore, it was felt that participation in the research study might serve an educational purpose by enhancing respondents' insight into, and awareness of, the profession of speechlanguage pathology in relation to stroke rehabilitation.

\section{METHODOLOGY}

\section{AIM OF THE STUDY}

1. To investigate the knowledge and attitudes of final year occupational therapy, physiotherapy and speechlanguage therapy students, regarding the role of the speech-language therapist as a member of the stroke rehabilitation team in a hospital setting.

2. To descriptively compare the views of occupational therapy and physiotherapy students with those of speech-language therapy students.

\section{SUBJECTS AND CRITERIA FOR SELECTION}

Final year (fourth year) occupational therapy, physiotherapy and speech-language therapy students, registered at the University of the Witwatersrand were used as subjects in the study.

\section{RESEARCH DESIGN}

In order to achieve the aims of the study, a crosssectional survey research design was implemented which involved the administration of a questionnaire within a group setting.

\section{Questionnaire content}

The questionnaire consisted of 30 questions or items and was divided into four sections. A copy of the questionnaire is set out in Appendix A.

Section $\boldsymbol{A}$ consisted of two closed-ended questions that elicited biographical information.

Section $B$ consisted of open-ended and closed-ended questions that focused on rehabilitation and teamwork.

\section{Section $C$}

This section consisted of questions that required the subjects to indicate which professional(s) would be responsible for various aspects of the stroke patient's rehabilitation. These aspects included :- motor recovery of limbs; the treatment of communication problems; emotional adjustment of the patient; family and social support; cognitive rehabilitation; and the management of long-term occupation. These questions were included to ascertain whether the respondents felt that more than one discipline would be responsible for each aspect of the stroke patient's rehabilitation, i.e., role duplication/ overlapping, and whether each group of students tended to assign most aspects of stroke rehabilitation to their own profession. In addition, the researcher attempted to establish each student group's perception regarding the speech-language therapist's role or responsibility in the above-mentioned aspects of stroke rehabilitation.

\section{Section $D$}

This section consisted of 15 statements encompassing the diversity of disorders which may present post stroke, and with which the speech-language therapist might be involved, such as Aphasia, Dysarthria, Apraxia and Dysphagia.

\section{PROCEDURE}

\section{a) Piloting the questionnaire}

Questionnaires were distributed to a recently qualified speech therapist, an occupational therapist and a physiotherapist, all of whom work with stroke patients in a hospital setting. Following the pilot study, certain questions were modified and rephrased.

\section{b) Administration of the questionnaire}

Sixty-seven questionnaires were distributed to students and collected during the same afternoon by the researcher.

\section{TREATMENT OF DATA}

Descriptive statistics comprising pie-charts and tables, with frequencies and percentages were employed. Those questionnaire items that were presented in the form of a Likert scale, were analyzed according to a three-category system. The five-category system was reduced to a three-category system. Therefore, "strongly agree" and "agree" categories were combined, as well as the "strongly disagree" and "disagree" categories. The "undecided" category remained unchanged. Open-ended questionnaire items were described both quantitatively and qualitatively.

\section{RESULTS AND DISCUSSION}

(Limitation of space precludes the inclusion of figures or tables to illustrate all the questions.)

\section{SECTION A}

\section{Question 1A}

The pie-charts in Figure 1 represent the percentage of respondents who indicated that they either had or had not, worked with stroke patients respectively. It is interesting to note that $42,9 \%$ of the speech-language therapy students had not worked with stroke patients. The reason for this may possibly be attributed to the fact that only in their fourth year of study, are speechlanguage therapy students provided with the opportunity to work with stroke patients. This opportunity arises either during a six week hospital block, or at the Speech and Hearing Clinic at the University of the Witwatersrand. In comparison, only 23,1 percent of physiotherapy students had no experience working with stroke patients, while all occupational therapy students had worked with the latter.

\section{Question $1 B$}

Ninety percent of the occupational therapy students, and $57,7 \%$ of the physiotherapy students reported that they had worked with stroke patients who had communication problems. This may have influenced the occupational students' understanding of communication disorders post-stroke, as well as the speech-language therapist's role in the stroke patient's rehabilitation. 


\section{Question 2A}

The physiotherapy and occupational therapy students were requested to indicate whether they had contact with speech-language therapists during their clinical blocks, while the speech-language therapy students were requested to indicate whether they had contact with occupational therapists and/or physiotherapists. Findings reflected similar percentages of contact suggesting that all three student groups may have been equally exposed to other rehabilitation specialities.

\section{Question 2B}

This question required occupational therapy and physiotherapy students to specify where they had made contact with speech-language therapists, and speech-language therapy students were requested to specify where they had made contact with occupational therapists and/or physiotherapists. Twenty physiotherapy students $(76,9 \%)$ and 15 occupational therapy students $(75 \%)$ had made contact with speech-language therapists, while 15 speech-language therapy students $(71,4 \%)$ had made contact with occupational therapists and/or physiotherapists. Most contact appeared to occur within the hospital setting, while all three student groups indicated that they had been exposed to other therapists at schools for cerebral palsied children such as Forest Town School.

\section{SECTION B}

\section{Question 1 - Definition of Rehabilitation}

Nichols (1976), suggests that all clinicians should be concerned with the rehabilitation of their patients, but there are many who will not have had the opportunity as students to develop an understanding of the wider aspects of patient care called "rehabilitation."

In analyzing the definitions of rehabilitation put forward by the physiotherapy, occupational therapy and speech-language therapy students, the salient points (dis- played in Table 1 below) of current definitions of rehabilitation by Gloag (1985), Gresham (1986), Galley \& Forster (1987), Purtilo (1988), Walker (1988) and Chamberlain (1989), were taken into account. Table 1 below highlights the percentage of respondents for each group, which included these prominent features in their definitions of rehabilitation.

The emphasis of point one in Table 1 is that rehabilitation aims at helping the individual reach his/her maximal potential. A relatively lower percentage of speech-language therapy students mentioned this point in their definitions of rehabilitation, while its prominent occurrence in the majority of current definitions in the literature is evident.

Point two of Table 1 highlighted the various aspects with which rehabilitation is concerned. A relatively higher percentage of physiotherapy students included this point in their definitions, which is also found in most definitions in the literature.

While some of the physiotherapy and occupational therapy students mentioned the goal of working toward patient independence (point three), none of the speechlanguage therapy students mentioned this factor.

It is interesting to note that a very low percentage of respondents across all student groups, mentioned the holistic nature of rehabilitation (point five). This finding may possibly be attributed to the fact that students are not provided with the opportunity to work within an interdisciplinary, holistic environment. This implies that students might not see themselves as members of a larger stroke rehabilitation team, but rather perceive themselves as being the exclusive providers of occupational, speech and physiotherapy respectively.

On the whole, the speech-language therapy students provided the narrowest definitions of rehabilitation, suggesting a possible under-emphasis of this concept during their theoretical and clinical training.

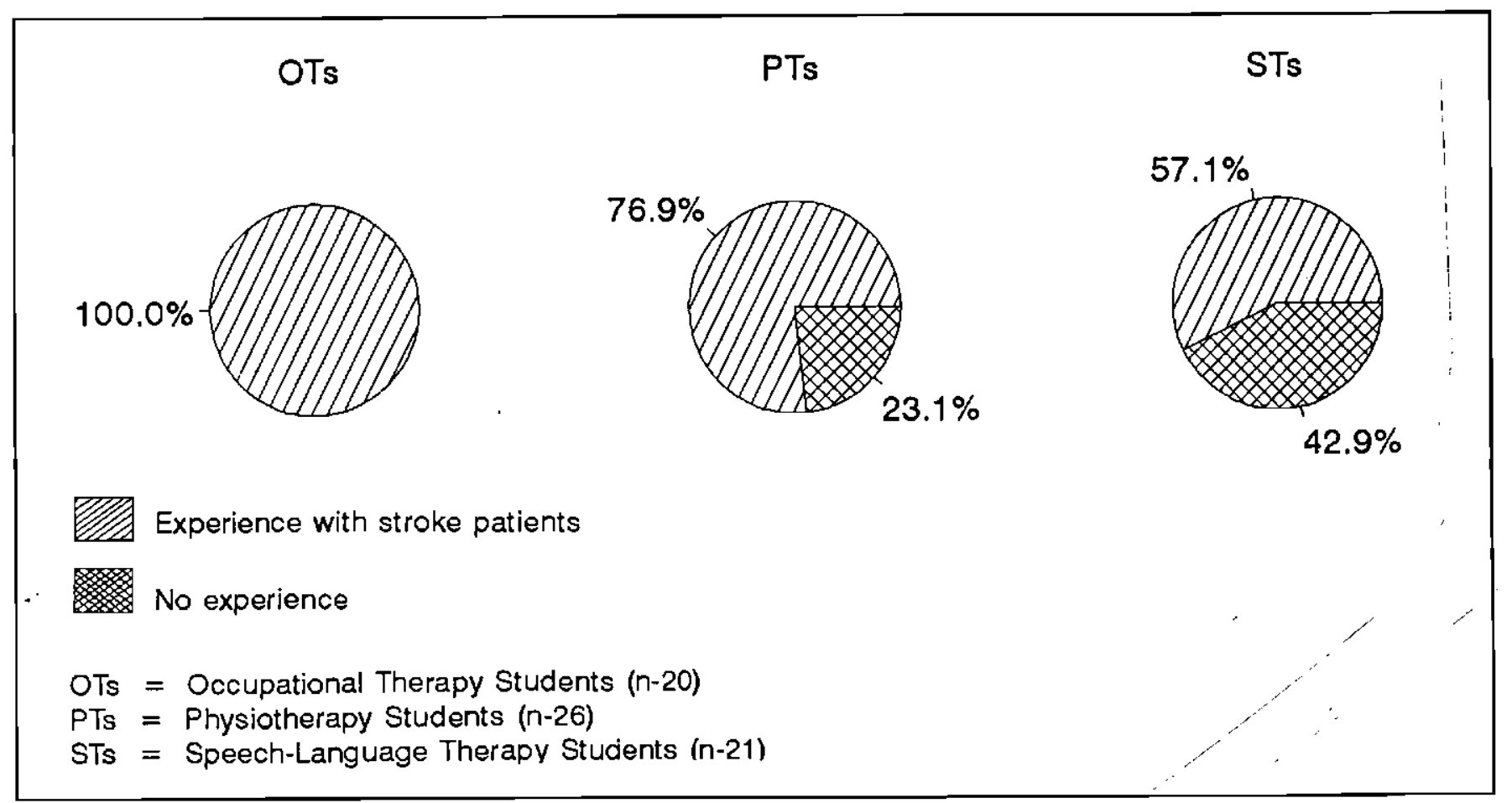

Figure 1. Experience with stroke patients 


\section{Question 2: Definition of Teamwork}

Brill (1976) states that teamwork has a variety of meanings, but valid generalizations can be made about it. In his definition of teamwork, Brill (1976, p.22) highlights four essential points.

1) A team is a group of individuals, each of whom is responsible for making decisions.

2) Each particular member possesses particular expertise.

3) Team members hold a common purpose.

4) Team members communicate, collaborate and consolidate knowledge together from which plans are made, actions are determined and future decisions influenced.

In analyzing the respondents' definitions of teamwork, many points consistent with those made by Brill (1976) were evident. Represented in Table 2 below, are the per- centages of respondents who included these points in their definitions.

\section{Question 3A +3B : Advantages of Teamwork}

Kane (1975, p.12) and Brill (1976, p.26) delineate the following advantages of teamwork for professionals:

1) Simplified access to and communication with other professionals.

2) Promotion of learning.

3) Awareness that the work of others can facilitate one's own work.

4) Co-ordination of skilled services for the patient.

5) Avoidance of duplication.

6) Teamwork provides a more comprehensive but integrated range of services.

7) Teamwork provides a forum for examination and evaluation of ideas in the light of the differing frames of reference of the various members.

\section{Table 1. Definition of rehabilitation}

\begin{tabular}{|c|c|c|c|}
\hline & PT & OT & ST \\
\hline $\begin{array}{l}\text { 1. Rehabilitation involves the treatment and the training of the patient so that } \\
\text { he/she may obtain his/her maximal potential for normal living, given the } \\
\text { constraints imposed by illness or injury. }\end{array}$ & $61,5 \%$ & $70,0 \%$ & $23,8 \%$ \\
\hline $\begin{array}{l}\text { 2. Rehabilitation embraces the physical, social, vocational and mental aspects of the } \\
\text { patient's life. }\end{array}$ & $73,1 \%$ & $30,0 \%$ & $19,0 \%$ \\
\hline 3. The emphasis is on improving the patient's capability to function independently. & $11,5 \%$ & $25,0 \%$ & $0,0 \%$ \\
\hline $\begin{array}{l}\text { 4. A habit of identifying potential compensating strengths in a person's functioning, } \\
\text { as it is not what the patient has lost but what he has left that is important. }\end{array}$ & $7,7 \%$ & $25,0 \%$ & $19,0 \%$ \\
\hline $\begin{array}{l}\text { 5. Rehabilitation is undertaken by doctors in co-operation with physiotherapists, } \\
\text { occupational therapists, social workers, speech-language therapists, psychologists } \\
\text { and nurses in an attempt to treat a patient holistically. }\end{array}$ & $7,7 \%$ & $10,0 \%$ & $4,8 \%$ \\
\hline 6. Returning the patient to a premorbid state of living as far as possible. & $23,1 \%$ & $20,0 \%$ & $33,3 \%$ \\
\hline
\end{tabular}

Percentages do not add up to 100 as respondents could include more than one feature in their definitions.

Table 2. Definition of teamwork

\begin{tabular}{|c|c|c|c|}
\hline & PT & OT & ST \\
\hline 1. Teamwork involves a group of individuals. & $42,3 \%$ & $65,0 \%$ & $71,4 \%$ \\
\hline $\begin{array}{l}\text { 2. Teamwork involves co-operation, communication and collaboration of ideas and } \\
\text { information. }\end{array}$ & $42,3 \%$ & $20,0 \%$ & $28,6 \%$ \\
\hline 3. Each member has particular expertise in his/her field. & $3,8 \%$ & $40,0 \%$ & $14,3 \%$ \\
\hline 4. There are common goals, aims or plans of action. & $30,8 \%$ & $10,0 \%$ & $28,6 \%$ \\
\hline 5. Teamwork is an approach that achieves optimal benefit for the patient. & $3,8 \%$ & $20,0 \%$ & $28,6 \%$ \\
\hline $\begin{array}{l}\text { 6. There is complementation of different treatments, and reinforcement of behaviours } \\
\text { taught in other therapies. }\end{array}$ & $11,5 \%$ & $5,0 \%$ & $4,8 \%$ \\
\hline 7. Teamwork is a holistic approach to patient care. & $0,0 \%$ & $5,0 \%$ & $0,0 \%$ \\
\hline 8. Teamwork includes the patient, his/her family, and other lay people. & $7,7 \%$ & $35,0 \%$ & $23,8 \%$ \\
\hline
\end{tabular}

Percentages do not add up to 100 as respondents could include more than one feature in their definitions. 
The responses to Question $3 \mathrm{~A}$ showed that the majority of respondents in each student group, were in agreement regarding the possible advantages of teamwork. The majority of respondents agreed that teamwork is an experience in participatory learning (3A.1), that teamwork provides for an exchange of ideas (3A.3) and that teamwork focuses on goals for mutual effort (3A.4). There was one hundred percent agreement across student groups that the holistic approach to teamwork (3A.2) is advantageous. Finally, responses to statement 3A.5 (teamwork provides an overlap of services) showed greater variability. Less than ten percent of respondents in each group were in disagreement with this statement. The majority of respondents (over eighty percent in all groups) however, were in agreement that the overlap of services in teamwork is beneficial.

Item 3B, an open-ended question, requested the respondents to add any further possible advantages of teamwork. Forty-eight percent of the speech-language therapy students, $54 \%$ of the physiotherapy students and $55 \%$ of the occupational therapy students, all contributed further advantages, namely,

- There is a support system for professionals.

- Goals are prioritised in terms of the whole patient.

- Teamwork breaks down professional barriers.

\section{Question 4A + 4B - Disadvantages of Teamwork}

"It is naïve to bring together a highly diverse group of people and expect that, by calling them a team they will in fact behave as a team" (Wise, Beckard, Rubin \& Kyte, 1974, p.56).

In the light of the above quote, it is important to acknowledge the possible problems that may arise when professionals work within a team. Brill (1976), Schlesinger (1985), and Germain (1984) point out the major downfalls of teamwork, namely,

1) The team situation fosters undesirable competition.

2) Problems of role definition and frequent overlap.

3) There are major problems of communication in teams.

4) Team meetings are often time-consuming.

5) Health professionals often have insufficient know- ledge about the education and expertise of other disciplines.

6) Health professionals tend to assign most tasks to their own profession rather than to others.

7) Disagreement with the goals of treatment.

The responses to Question $4 \mathrm{~A}$, that consists of seven statements concerning the possible disadvantages of teamwork, showed greater variability relative to the responses to question 3A. Approximately $70 \%$ of respondents in each group were in agreement that a lack of knowledge of what other team members do (question 4A.5) is a disadvantage of teamwork. Furthermore, the majority of respondents in each student group, were also in agreement that problems of role definition (question 4A.4) may be a possible downfall of teamwork. These findings highlight the need to educate students of all three professional disciplines, regarding the roles and functions of other rehabilitation specialities.

The second part of question 4, required respondents to add any other possible disadvantages of teamwork. Ten percent of both speech-language therapy and occupational therapy students, and four percent of physiotherapy students, contributed further disadvantages, namely,

- Personality clashes between team members.

- Professionals, for example doctors, may doubt the efficacy of the other professionals' therapies.

- There may be too many opinions.

- Professionals may give contradictory suggestions for therapeutic intervention.

\section{Question 5A and 5B}

According to Galley \& Forster (1987), Wade et al., (1985), and Dean \& Geiringer (1990), the doctor or physician tends to be the leader of the team. Bonner (1969) states that all members of the team look to the doctor for guidance, direction and enlightenment, while Dean \& Geiringer (1990) propose that the physician is skilled in integrating a complex patient-care system. In contrast with the above view, Wade et al., (1985) state that doctors take a less-than-active role, leaving the deci-



Figure 2. Leadership of the rehabilitation team. 
sions to the other team members. In a research study conducted by Motona \& Nowitz (1991), qualified physiotherapists were asked to give their opinion regarding who should be primarily in charge of a rehabilitation team. The majority of respondents indicated that the physiotherapist should be in charge of the team, while approximately one third of the respondents believed that leadership should be shared. This finding suggests that there is a movement away from the doctor-led team

Figure 2. depicts in the form of pie-charts, the percentages of respondents, who indicated that leadership should be shared by more than one professional of the team, and those who expressed that only one professional of the team should be in charge.

The respondents who indicated that one professional should lead the team, mentioned the doctor, the social worker and the occupational therapist as being sole leaders. It is interesting to note that not one of the physiotherapy respondents indicated that the doctor should lead the rehabilitation team. This may possibly be due to the fact that physiotherapists do not require patient referrals from doctors (Beenhakker, 1991), while under the current legislation, occupational therapists and speech-language therapists have to have their patients referred to them by a registered medical practitioner (South African Medical and Dental Council, Act 56).

of the respondents who indicated that leadership should be shared among professionals, four main combinations of leaders emerged, namely

1) All members should share leadership.

2) The speech-language therapist, the occupational therapist, and the physiotherapist.

3) The speech-language therapist, the occupational therapist, the physiotherapist and the social worker.

4) The speech-language therapist, the occupational therapist, the physiotherapist and the psychologist.

\section{Question 6A and 6B}

Beenhakker (1991, p.8) suggests that "for professionals to be able to work together as a team, they need to study together as students." She believes that this encourages a greater understanding of health professionals' mutual problems, and will establish co-operative behaviour patterns. Beenhakker (1991) further adds that to date, this is not being achieved at the University of the Witwatersrand, Medical School, and probably at very few other training institutions.

Beenhakker (1991, p.8) emphasises the need for students to campaign for a "multidisciplinary approach to teaching from their first year of study". Only then may students learn from an early stage the "mechanics of multidisciplinary activities and the particular expertise of the individual professions."

In a reseàrch study conducted by Waller \& Murphy (1985, p.19-22) qualified speech-language therapists who worked in hospital settings, were questioned as to whether they felt a need for more knowledge of rehabilitation specialities such as occupational therapy, physiotherapy and social work. Approximately $50 \%$ of the respondents indicated that in "some cases", they could use more information on all rehabilitation specialists. In addition, when asked about course lectures received in their undergraduate training, regarding other rehabilitation specialists, $80,6 \%$ of the respondents stated that no courses on occupational therapy were covered, while $77,6 \%$ of the respondents indicated that courses on physiotherapy had not been given.

Question 6A requested respondents to indicate their attitudes to the statement read as follows:- "For professionals to be able to work together as a team, they need to work together as students." The pie-charts in Figure 3 indicate the percentage of respondents who were in agreement, disagreement and who were undecided about the above statement.



Figure 3. Working together as students 
Speech-language therapy students unanimously agreed with the above statement. This may be attributed to the fact that speech-language therapy students at the University of the Witwatersrand are not part of the medical campus and have no contact with occupa. tional therapy and physiotherapy students. Occupational therapy and physiotherapy students are both situated on the medical school campus, and have formal lectures together for the first two years of their four year course. Occupational therapy and physiotherapy hospital departments are located in close physical proximity and thus more interaction occurs between these two professional disciplines.

Some of the comments made in agreement with the statement were as follows:

- It is important to build rapport and understanding of each other's professions at a student level.

- There is little communication between students of different disciplines.

- A basic foundation of mutual co-operation must be instilled in students.

- We must learn to respect and appreciate other disciplines.

- This is not being done at present, largely due to the lack of communication between members of staff of the various disciplines.

- I have never in my three and a half years worked with another student, nor received formal information on the roles of other professionals.

Some comments made by those respondents who were undecided about the statement were as follows:-

- Although professions overlap, there is no need for specific interaction.

- When qualified, it should be just as easy to move into a team approach.

The following comments were made by those respondents who were in disagreement to Question $6 \mathrm{~A}$.

- Students are still trying to prove themselves to their peers.

- As professionals, people feel on a more equal footing.

- Professionals can quickly learn to work together once qualified.

\section{SECTION C}

Bluestone (1976, p.14) aptly sums up both the advantages and disadvantages of role duplication. She states that "because of the overlapping interests of the various professions, a definition of roles is needed to avoid both gaps and duplication". On the other hand, "cross-fertilisation of skills permits valuable reinforcement" of each professional's treatment by the other health professionals on the team, for example the social worker and the speech-language therapist both may be counselling the patients about their reduced but active role in the family.

Wade et al., (1985, p.322) made the following suggestions regarding which team professionals would be responsible for different aspects of stroke rehabilitation, most of which were included in the research questionnaire. They saw the physiotherapist and the occupa- tional therapist as being involved in the motor recovery of limbs. The occupational therapist, the physiotherapist and the nurse were the three team members seen to be responsible for rehabilitation of activities of daily living such as feeding, grooming and bathing. Wade et al., (1985) further stated that the speech-language therapist, the psychologist and the social worker were responsible for emotional adjustment of the patient, while they suggested that the social worker, the psychologist, friends, religious advisors and the speechlanguage therapist were responsible for family and social support. The rehabilitation of communication problems was seen to be in the professional realm of both the speech-language therapist and the psychologist. Finally, the social worker and the occupational therapist were the two members who were perceived to be involved in the patient's long-term occupation. Ylvisaker and Urbanczyk (1990) comment on cognitive rehabilitation, and view it as being an inter-disciplinary attempt to overcome cognitive obstacles which may result from a stroke, such as impairment of memory. While the role of the neuropsychologist in cognitive rehabilitation has been primarily diagnostic (Turnbull, 1992), it is felt that the speech-language therapist and the occupational therapist fulfil a more therapeutic role in the rehabilitative efforts of impaired cognitive abilities.

Each of the seven aspects of stroke rehabilitation are discussed separately as follows. Of those respondents who indicated that more than one professional is involved in motor recovery of limbs (Question one), 60\% of the occupational therapy students, $26,9 \%$ of the physiotherapy students and $14,3 \%$ of the speech-language therapy students, indicated that the occupational therapist and the physiotherapist would be jointly involved in this aspect of rehabilitation.

In question two, $45 \%$ of the occupational therapy students, $27 \%$ of the physiotherapy students, and $14,3 \%$ of the speech-language therapy students, indicated that the occupational therapist is exclusively responsible for the rehabilitation of activities of daily living. Twenty percent of the occupational therapy students and 11,5\% of the physiotherapy students indicated that the speechlanguage therapist would have a role to play in this aspect of stroke rehabilitation, while almost half $(47,6 \%)$ of the speech-language therapy students felt that they had a role to play in the rehabilitation of activities of daily living. This important finding may possibly be attributed to the fact that the speech-language therapist is frequently involved in the diagnosis and treatment of Dysphagia, which can be viewed as an essential function of daily living.

In question three, a substantially large percentage of students across all three groups indicated that more than one professional would be responsible for the emotional adjustment of the patient. This finding may possibly be attributed to the fact that all members of the team receive some form of training in counselling skills, in their student education.

It is interesting to note that for the rehabilitation of communication problems (in question 4), substantially higher percentages of occupational therápy and physiotherapy respondents indicated that only one professional, i.e., the speech-language therapist, should be involved in this aspect. In comparison to these findings, $71,4 \%$ of the speech-language therapy students indi- 
cated that rehabilitation of communication problems involved more than one team member. This finding suggests that speech-language therapy students do not see themselves as exclusively responsible for the rehabilitation of communication disorders, but rather see other team members as also being valuable contributors to communication rehabilitation.

Question 5 dealt with the aspect of family and social support. While $25 \%$ of the occupational therapy students, $19 \%$ of the physiotherapy students and $9,5 \%$ of the speech-language therapy students, indicated that the social worker is exclusively responsible for this aspect, there was a substantially high percentage of respondents in each group who felt that family and social support is given by more than one professional. It is interesting to note that more than half $(54,4 \%)$ of the speech-language therapy respondents felt that they had a role to play in family and social support, while only $30 \%$ of the occupational therapy students and $34,6 \%$ of the physiotherapy students mentioned the speech therapist's role in this aspect.

Of those respondents who indicated that more than one professional is responsible for cognitive rehabilitation (question 6 ), $30 \%$ of the occupational therapy students and $23 \%$ of the physiotherapy students indicated that the occupational therapist and the speech-language therapist are jointly responsible. Nineteen percent of the speech-language therapy students mentioned that in addition to the occupational and speech-language therapists, the family and the psychologist are also responsible for rehabilitation of impaired cognitive abilities. It is interesting that an extremely high percentage $(95,2)$ of speech-language therapy students felt that they had a role to play in cognitive rehabilitation, compared with $61,5 \%$ of the physiotherapy students and only $35 \%$ of the occupational therapy students who indicated the involvement of the speech-language therapist. The reason for only $35 \%$ of occupational therapy students mentioning the speech-language therapist's role in cognitive rehabilitation, may possibly be attributed to the fact that occupational therapy students view cognitive rehabilitation as falling within their own professional realm.

The final aspect of stroke rehabilitation is that of long-term occupation (Question 7). Haydock (1992) states that the patient's ability to return to his or her previous employment may/have to be assessed by the occupational therapist. Thirty-five percent of the occupational therapy students, and $31 \%$ of the physiotherapy students mentioned that both the occupational therapist and the social worker need to be involved in longterm occupation of the patient, while $14,3 \%$ of the speech-language therapy students indicated that the family should be involved together with the occupational therapist and the social worker. It is important to note that $35 \%$ of the occupational therapy students saw their profession as being exclusively involved in long-term occupation. It is also interesting to note that $33,3 \%$ of the speech-language therapy students mentioned their involvement, together with other team members, in the aspect of long-term occupation. This finding may possibly be attributed to the fact that communication disabilities often impinge upon vocational aspects of the patient's life.

\section{SECTION D - THE ROLE OF THE SPEECH- LANGUAGE THERAPIST}

As mentioned previously, four of the most common disorders resulting from a stroke, in which the speechlanguage therapist plays an active role are Aphasia, Dysarthria, Apraxia and Dysphagia.

Logemann (1990, p.157) states that the role of the speech-language therapist in Dysphagia encompasses evaluation and treatment of dysphagic patients. In question 3, there was one hundred percent agreement from both occupational and speech-language therapy students, and $96,2 \%$ agreement from the physiotherapy students, regarding the active role of the speech-language therapist in the treatment of Dysphagia.

Penn (1992), Simmons (1981), Clifford-Rose \& Capildeo (1981) and Softley (1987), all stress the active role of the speech-language therapist in the treatment of Aphasia. Similarly, respondents in each student group were all in total agreement regarding the role of the speech-language therapist in the treatment of Aphasia.

As with the treatment of Aphasia, Penn (1992), Simmons (1981), Clifford-Rose \& Capildeo (1981) and Softley (1987) all emphasise the role that the speechlanguage therapist plays in the diagnosis and treatment of Verbal Apraxia or Apraxia of Speech. One hundred percent of both occupational therapy and speech-language therapy students agreed that the speech-language therapist is actively involved in the treatment of Verbal Apraxia, while only $84 \%$ of the physiotherapy students were in agreement. One hundred percent agreement of occupational therapy students in comparison with $84,6 \%$ agreement of the physiotherapy students, may possibly be attributed to the fact that occupational therapy students diagnose and treat other types of Apraxia such as Dressing Apraxia, Limb Apraxia, and Constructional Apraxia (Thompson \& Morgan 1990).

The role of the speech-language therapist in the treatment of Dysarthria, has also been highlighted by various authors including Penn (1992) and Softley (1987). In question 12, there is unanimous agreement on the part of both occupational and speech-language therapy students, while $96,2 \%$ of the physiotherapy students agreed that the speech-language therapist plays a role in the treatment of Dysarthria.

Thus, it appears that both occupational therapy and physiotherapy students are well informed, with regard to the four main disorders post-stroke, with which a speech-language therapist would be actively involved. In addition, these four most common disorders are intensively covered in the latter two years of the fourth year speech-language therapy course.

It is interesting to note that, while both occupational and physiotherapy students were in one hundred percent agreement regarding the role of the speech-language therapist in the treatment of Auditory Agnosia (Question 14), only $80,9 \%$ of the speech-language therapy students agreed with question 14's statement. Auditory Agnosia, together with Visual Object Agnosia, Visual Spatial Agnosia and Tactile Agnosia, is a disorder of perception that may be present following a stroke (Thompson \& Morgan, 1990). The lower percentage of agreement within the speech-language therapy group, may possibly be attributed to the fact that Auditory 
Agnosia and the clinical treatment thereof, is less intensively covered in their academic curriculum. In addition there appears to be a paucity of literature, covering the role of the speech-language therapist in the treatment of Auditory Agnosia.

To date, there appears to be lack of clarity regarding the role of the speech-language therapist in the treatment of Agraphia as well as Alexia. While both disorders imply a loss or impairment of some mode of communication, the speech-language therapist's role in such disorders is unclear. Penn (1992) differentiates between difficulties of reading and writing that arise from different problems. Reading and writing difficulties that arise from sensori-motor deficits such as Hemianopsia and Hemiplegia, must not be confused with reading and writing problems that are a result of difficulty in comprehending or producing the written word respectively. This suggests that both the speech-language therapist and the occupational therapist should have a role to play in the treatment of Alexia and Agraphia. Furthermore, reading and writing difficulties that arise from sensorimotor deficits should fall within the professional realm of the occupational therapist, whereas reading and writing difficulties that are a function of a greater language impairment should fall within the ambit of speech-language therapy.

In questions four and five, occupational therapy stu. dents in comparison with physiotherapy and speech-language therapy students were in the least agreement, and were the most undecided about the speech-language therapist's role in the treatment of Agraphia and Alexia respectively. It is interesting to note that $76,2 \%$ of the speech-language therapy students agreed that they had a role to play in the treatment of Agraphia, while $85,7 \%$ of the speech-language therapy students were of the opinion that they could contribute to the treatment of Alexia.

Question 11 dealt with the role of the speech-language therapist in the treatment of Amnesia. The view that cognitive rehabilitation, which includes the treatment of Amnesia, should be a broad-based, functional and inter-disciplinary effort (Ylvisaker \& Urbanczyk $1990)$ suggests that more than one professional discipline has a role to play in cognitive rehabilitation. It is interesting to note that, while $100 \%$ of the speech-language therapy students felt that their profession had a part to play in the treatment of Amnesia, only $30 \%$ of the occupational therapy students were in agreement with this. This finding is consistent with that of question 6 in Section C, which suggests that occupational therapy students may view the treatment of Amnesia (an aspect of cognitive rehabilitation), within their own professional field. Similarly, speech-language therapy students may see the treatment of Amnesia, as exclusively belonging to their discipline.

\section{CONCLUSION}

In summary, results of this study suggested a fairly good understanding of the concepts of rehabilitation and teamwork. However, speech-language therapy students provided the narrowest definition of rehabilitation suggesting a possible under-emphasis of this concept in their clinical and theoretical training. Students appeared to have a greater understanding of those disor- ders post-stroke, with which a speech-language therapist is commonly involved. However, students showed less understanding of those disorders following a stroke, for which the speech-language therapist's role is less clearly defined. In addition, a high percentage of role duplication/overlapping in the several aspects of stroke rehabilitation was found. These results hold important implications for the profession of speech-language pathology in the 1990's in terms of undergraduate and postgraduate inter-disciplinary education, clarification of the speech-language therapist's clinical role, public relations, and for further research.

\section{Inter-disciplinary education}

Inter-disciplinary education at both undergraduate and postgraduate levels should be a joint and reciprocal way in which health care professionals can learn from and about each other. This could be achieved in a number of possible ways, namely,

i) Inter-departmental case presentations on a regular basis whereby cases would be presented from different frames of reference.

ii) Collaborative research involving students from various disciplines.

iii) Joint rural/community blocks - at present, only final year occupational therapy and physiotherapy students attend a three-week rural block.

iv) Seminars or a series of lectures covering other paramedical professionals' roles in stroke and other rehabilitation.

v) Improving inter-departmental links between both staff members and students alike.

vi) Setting up student rehabilitation clinics, allowing students to work in a holistic environment.

\section{Speech-language therapist's clinical role}

The results of this study suggested that occupational therapy, physiotherapy and speech-language therapy students acknowledged the role of the speech-language therapist in the treatment of such disorders as Aphasia, Dysarthria, Verbal Apraxia and Dysphagia, with which the speech-language therapist is commonly associated. However, students showed less understanding of such disorders as Amnesia, Alexia and Agraphia, for which the speech-language therapist's role is not as well defined. This finding implies the need to clarify the speech-language therapist's clinical role, as well as other paramedical therapist's roles in such disorders.

\section{Public relations}

There appears to be the need for speech-language and hearing therapists to market their profession. Van Hattum (1980) maintains that it is ironic that a profession devoted to the treatment of communication disorder has had so much difficulty communicating this information. Thus, the profession of speech-language and hearing therapy needs to perform an educative role, which could be achieved in a number' of ways:

1) Through academic contributions to medical and paramedical journals of South Africa. .

2) Through explanatory pamphlets or audio-visual media outlining the role of the speech-language and hearing therapist in the treatment of different com- 
munication disorders.

3) Through workshops, orientation programmes or professional forums for medical and paramedical students and professionals throughout their programs.

\section{Suggestions for further research}

1. Replication of the present study, using a similar or the same questionnaire, on qualified occupational, speech and physiotherapists, to establish the extent to which their attitudes and knowledge are related to increased experience.

2. Evaluation of an existing inter-disciplinary stroke rehabilitation team, to assess the effectiveness of such an approach for future teamwork practise.

3. Investigation of the knowledge and attitudes of final year social work and/or nursing students, as well as medical doctors specialising in neurology, regarding the role of the speech-language therapist in the hospital stroke rehabilitation team.

4. Investigation of the attitudes and knowledge of medical doctors specialising in ear, nose and throat sur. gery, towards the speech-language and hearing therapist's role in the cleft-palate or laryngectomy team.

5. Investigation of the attitudes and knowledge of occupational therapy and physiotherapy students, regarding the speech-language therapist's role in the inter-disciplinary management of cerebral palsied children.

Brill (1976, p.143) maintains that "the great need of the student in intra- and intergroup relations is not only for knowledge of the groups involved but also for the ability to reach across these boundaries while at the same time respecting them". It is hoped that this study will promote a general awareness of the need to gain knowledge and understanding of the roles that various paramedical professionals play in stroke rehabilitation and ultimately lead to more effective and holistic patient management.

\section{REFERENCES}

Beenhakker, J.C. (1991). Role of the Physiotherapist in the Health Team. The Leech 60,2,8 -9.

Bluestone, S.S. (1976). Rehabilitation Medicine. In Haller, R.M. \& Sheldon, N. (Eds.) Speech Pathology and Audiology in Medical Settings. New York: Stratton Intercontinental Medical Book Corporation!

Bonner, D. (Ed.) (1969). The Team Approach to Hemiplegia. Illinois: Charles Thomas Publisher.

Boone, P.R. (1987). Human Communication and its Disorders. New Jersey: Prentice Hall Incorporated.

Brill, N.I. (1976). Teamwork - Working Together in the Human Services. Philadelphia: J.B. Lippincott Company.

Chamberlain, M.A. (1989). What is Rehabilitation ? Br. J. Hosp. Med., 41,311.

Clifford-Rose, C. \& Capildeo, R. (1981) Stroke: The Facts. Oxford University: New York Press.

Dean, B.Z. \& Geiringer, S.R. (1990). Psychiatric Therapeutics. 6. The Rehabilitation Team/ Behavioural Management. Arch. Phys. Med. Rehabil., 71, 4, s-275-s-276.

Fritz, V. (1992). The Medical Perspective. In Fritz, V. \& Penn,C. (Eds). Stroke: Caring and Coping. Johannesburg: Witwatersrand Medical Press.

Fritz, V. \& Penn,C. (Eds) (1992), Stroke: Caring and Coping. Johannesburg: Witwatersrand Medical Press.
Galley, P.M. \& Forster, A.L. (1987). Human Movement: An Introductory Text for Physiotherapy Students. Second Edition, New York: Churchill Livingstone.

Germain, C.B. (1984). Social Work Practise in Health Care: An Ecological Perspective. New York: The Free Press.

Gloag, D. (1985). Severe Disability: Tasks of Rehabilitation. Br. Med. J., 290, 1333-1336.

Gresham, G.E. (1986). The Rehabilitation of the Stroke Survivor. In Barnett, H.J.M. (Ed). Stroke: Pathophysiology, Diagnosis and Management. New York: Churchill Livingstone.

Haller, R.M. \& Sheldon, N. (1976). Speech Pathology and Audiology in Medical Settings. New York: Stratton Intercontinental Medical Book Corporation.

Haydock, S. (1992). Occupational Theräpy. In Fritz, V. \& Penn, C. (Eds) Stroke Caring and Coping. Johannesburg: Witwatersrand University Press.

Kane,R.A. (1975) Interprofessional Teamwork. Syracuse: New York Syracuse University Press.

Logemann, J. (1990), Dysphagia. Sem. Speech Lang. 11,3,157163.

Love, R.J. \& Webb, W.G. (1986). Neurology for the Speech. Language Pathologist. Boston: Butterworth Publishers.

Milner, M.(1989). Knowledge and Attitudes of Fifth Year Medical Students Concerning the Profession of Speech Therapy and Audiology. Unpublished Honours Research Project. Department of Speech Pathology and Audiology: University of the Witwatersrand.

Motona, B.S. \& Nowitz, L.M. (1991). Physiotherapists' Perceptions of Rehabilitation. Unpublished Honours Research Project. Department of Physiotherapy : University of the Witwatersrand.

Nichols, P.J.R. (1976), Rehabilitation Medicine: The Management of Physical Disabilities. London: Butterworth Publishers.

Penn, C.(1992). Management of Communication Problems. In Fritz, V. \& Penn, C. (Eds). Stroke: Caring and Coping. Johannesburg: Witwatersrand University Press.

Purtilo, R. (1988). Ethical Issues in Teamwork: The Context of Rehabilitation. Arch. Phys. Med. Rehabil. 69, 5, 318-322.

Schlesinger,E.G.(1985). Health Care Social Work: Concepts and Strategies. St. Louis:Mosby College Publishing.

Simmons, N.N. (1981). The Interaction Between Communication Disorders and Neurogenic Disorders. In Darby, J.K. (Ed) Speech Evaluation in Medicine. New York: Grune and Stratton.

Softley, L. (1987). Speech Therapy. In Kamal, A. (Ed) The Colour Atlas of Stroke: Cerebrovascular Disease and its Management. England: Wolf Medical Publishers.

South African Medical and Dental Council (Act 56)Government Gazette, 1986.

Stonnington, H.H. \& Browne, J.A. (1987). Team Approach to Management. In Brandstater, M.E. and Basmajian, J.V. (Eds) Stroke Rehabilitation. Baltimore: Williams and Wilkins.

Thompson, S.B.N. \& Morgan, M. (1990). Occupational Therapy for Stroke Rehabilitation. New York: Chapman \& Hall.

Turnbull, O. (1992). The Neuropsychology of Stroke. In Fritz, V. \& Penn, C. (Eds). Stroke: Caring and Coping. Johannesburg: Witwatersrand University Press.

Van Hattum, R.J. (Ed.) (1980). An Introduction to Communication Disorders. New York: Macmillan Publishing Company.

Wade, D.T., Langton-Hewer, R., Skilbeck, C.E. \& David, R.M (1985). Stroke: A Critical Approach to Diagnosis, Treatment, and Management. London: Chapman \& Hall.

Waller, M.R. \& Murphy, W.P. (1985). The Speech-Language Pathologist in a Medical Setting. ASHA, 25,19-22.

Walker, A. (1988). Rehabilitation: Micro-Market or Major Partner in Healthcare's Future. J. Rehabil. 54,1,19-22.

Wise, H., Beckard, R., Rubin, J., \& Kyte, A.L., (Eds) (1974). Making Health Teams Work. Cambridge: Ballinger.

Ylvisaker, M.S. \& Urbanczyk, M.S. (1990). The Efficacy of Speech-Language Pathology Intervention: Traumatic Brain Injury. Semin. Speech Lang. 11,4,215-224. 


\section{APPPENDIX A}

Views of Occupational Therapy, Physiotherapy and Speech-language therapy Students regarding the Role of the Speech Language Therapist in the Stroke Rehabilitation Team.

\section{Dear Final Year Students}

I am a final year speech-language therapy student at the University of the Witwatersrand. I am conducting an undergraduate research project regarding the role of the speech language therapist as a member of the stroke rehabilitation team. The study involves a questionnaire that seeks your opinions and attitudes.

I would sincerely appreciate your help in completing the questionnaire. All information given will be treated confidentially and results will be presented in aggregate, thus assuring your anonymity.

Sincerely thanks

L. Felsher

\section{QUESTIONNAIRE}

\section{SECTION A - BIOGRAPHICAL DATA (Occupational and Physiotherapy Students)}

1.A. Have you worked with stroke patients during your student training?

yes

no

1.B. If yes, did any of the stroke patients have communication problems?

yes

no

2.A. Have you ever had any contact with occupational therapists and/or physiotherapists during your clinical training blocks?

yes

no

2.B. If yes, please specify where

\section{QUESTIONNAIRE}

\section{SECTION A - BIOGRAPHICAL DATA (Speech-language therapy students)}

1.A. Have you worked with stroke patients during your student training ?

yes<smiles></smiles>

1.B. If yes, did any of the stroke patients have problems other than communication problems, e.g., hemiplegia ? yes

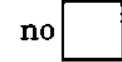

2.A. Have you ever had any contact with speech-language therapists during your clinical training blocks ?
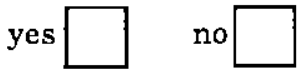

2.B. If yes, please specify where

\section{SECTION B - TEAMWORK AND REHABILITATION}

This section considers teamwork in relation to rehabilitation.

1." Define 'rehabilitation' in your own words.

2. Define 'teamwork' in your own words. 
3.A. Please indicate your answers to the following statements by placing a tick in ONE of the following blocks.

\begin{tabular}{|c|c|c|c|c|c|}
\hline Possible advantages of teamwork are : & $\begin{array}{l}\text { Strongly } \\
\text { agree }\end{array}$ & agree & undecided & disagree & $\begin{array}{l}\text { strongly } \\
\text { disagree }\end{array}$ \\
\hline $\begin{array}{l}\text { 1. Teamwork is an experience in } \\
\text { participatory learning. }\end{array}$ & & & & & \\
\hline $\begin{array}{l}\text { 2. Teamwork is a holistic approach } \\
\text { to patient management. }\end{array}$ & & & & & \\
\hline $\begin{array}{l}\text { 3. Teamwork provides an opportunity } \\
\text { for an exchange of ideas from } \\
\text { different frames of reference. }\end{array}$ & & & & & \\
\hline $\begin{array}{l}\text { 4. There is a focus on goals that } \\
\text { provide necessary direction for } \\
\text { mutual efforts. }\end{array}$ & & & & & \\
\hline $\begin{array}{l}\text { 5. There is an overlap of services } \\
\text { performed by more than one team } \\
\text { member. }\end{array}$ & & & & & \\
\hline
\end{tabular}

3.B. In your opinion, are there any other advantages of teamwork?

If so, please specify

4.A. Please indicate your answers to the following statements by placing a tick in $\underline{\text { ONE }}$ of the following blocks.

\begin{tabular}{|l|l|l|l|l|}
\hline $\begin{array}{l}\text { Possible disadvantages of teamwork } \\
\text { are: }\end{array}$ & $\begin{array}{l}\text { Strongly } \\
\text { agree }\end{array}$ & agree & undecided & $\begin{array}{l}\text { disagree } \\
\text { 1. Communication problems. }\end{array}$ strongly \\
\hline 2. Time consuming mejetings. & & & \\
\hline 3. Professional jealousy/competition. & & & & \\
\hline $\begin{array}{l}\text { 4. Problems of role definition, i.e., there } \\
\text { is an overlap of therapeutic } \\
\text { services. }\end{array}$ & & & & \\
\hline $\begin{array}{l}\text { 5. Lack of knowledge of what other } \\
\text { team members do. }\end{array}$ & & & & \\
\hline 6. Dispute for leadership of the team. & & & & \\
\hline $\begin{array}{l}\text { 7. Lack of co-operation between team } \\
\text { members. }\end{array}$ & & & & \\
\hline
\end{tabular}

4.B. In your opinion, are there any other disadvantages of teamwork?

If so, please specify 
5.A. Patient $X$ is a 55 year old male who suffered a stroke (left cerebral haemorrhage). He now presents with: a or impairment of the ability tove read), agrad side of his body), very limited expressive language, alexia (loss ), agraphia (loss or impairment of the ability to write), and severe depression.

The following professionals are all members of the rehabilitation team for patient $\mathrm{X}$. Who in your opinion should be primarily in charge of the stroke rehabilitation team for patient $X$ ?

(Please tick ONE box that corresponds to your answer.)



Occupational Therapist

Psychologist

Speech-language Therapist

Leadership shared by more than one professional

$\square$ Social Worker
$\square$ Physiotherapist
$\square$ Family
$\square$ Doctor

If so, please specify which professionals

5.B. Please give reasons for your choice of answer in question 5.A.

6.A. Please indicate to the following statement by placing a tick in one of the following blocks .

\begin{tabular}{|c|c|c|c|c|c|}
\hline & $\begin{array}{c}\text { Strongly } \\
\text { agree }\end{array}$ & agree & undecided & disagree & $\begin{array}{l}\text { strongly } \\
\text { disagree }\end{array}$ \\
\hline $\begin{array}{l}\text { For professionals to be able to work } \\
\text { together as a team, they need to work } \\
\text { together as students. }\end{array}$ & & & & & \\
\hline
\end{tabular}

6.B. Please comment on your answer to question 6.A

\section{SECTION C - STROKE REHABILITATION}

This section looks at the various aspects of stroke rehabilitation.

Please note the following abbreviations used in this section :
Dr. - Doctor
N. - Nurse
Fm - Family
PT - Physiotherapist

$$
\begin{aligned}
& \text { OT - Occupational Therapist } \\
& \text { ST - Speech-language Therapist } \\
& \text { SW - Social Worker } \\
& \text { Psy - Psychologist }
\end{aligned}
$$

Please tick ONE OR MORE of the following blocks that correspond(s) to your answer(s).

In your opinion, which professional(s) would be responsible for :- 


\begin{tabular}{|l|l|l|l|l|l|l|l|l|l|}
\hline & Dr. & N. & Fm & Pt & OT & ST & SW & $\begin{array}{c}\text { Ps } \\
\mathbf{y}\end{array}$ & $\begin{array}{c}\text { Other } \\
\text { (please specify) }\end{array}$ \\
\hline 1. Motor recovery of limbs. & & & & & & & & & \\
\hline $\begin{array}{l}\text { 2. Rehabilitation of activities } \\
\text { of daily living e.g., eating, } \\
\text { dressing. }\end{array}$ & & & & & & & & & \\
\hline $\begin{array}{l}\text { 3. Emotional adjustment of } \\
\text { the patient. }\end{array}$ & & & & & & & & & \\
\hline $\begin{array}{l}\text { 4. Treatment of } \\
\text { communication problems. }\end{array}$ & & & & & & & & & \\
\hline $\begin{array}{l}\text { 5. Family and social } \\
\text { support. }\end{array}$ & & & & & & & & & \\
\hline $\begin{array}{l}\text { 6. Cognitive rehabilitation } \\
\text { e.g., memory problems. }\end{array}$ & & & & & & & & \\
\hline $\begin{array}{l}\text { 7. Management of long-term } \\
\text { occupation. }\end{array}$ & & & & & & & \\
\hline
\end{tabular}

\section{SECTION D - ROLE OF THE SPEECH-LANGUAGE THERAPIST}

This section seeks your opinion regarding the role of the speech-language therapist in the following conditions that occur post-stroke/CVA.

Please indicate your answer to the following statements by placing a tick in one of the following blocks

\begin{tabular}{|c|c|c|c|c|c|}
\hline $\begin{array}{l}\text { The speech-language therapist has a } \\
\text { role to play in the treatment of : }\end{array}$ & $\begin{array}{l}\text { Strongly } \\
\text { agree }\end{array}$ & agree & undecided & disagree & $\begin{array}{l}\text { strongly } \\
\text { disagree }\end{array}$ \\
\hline $\begin{array}{l}\text { 1. Hemiplegia - the loss of movement on one side of } \\
\text { the body. }\end{array}$ & & & & & \\
\hline $\begin{array}{l}\text { 2. Hemianopsia - visual field defect on one half of the } \\
\text { eye field. }\end{array}$ & & & & & \\
\hline 3. Dysphagia - a neuromotor disorder of swallowing. & & & & & \\
\hline 4. Agraphia - loss or impairment of the ability to read. & & & & & \\
\hline 5. Alexia - loss or impairment of the ability to write. & & & & & \\
\hline $\begin{array}{l}\text { 6. Aphasia - loss or impairment of the ability to use } \\
\text { and/or understand language. }\end{array}$ & & & & & \\
\hline 7. Depression-sadnesș, despair, and discouragement. & & & & & \\
\hline $\begin{array}{l}\text { 8. Hemispatial neglect - tendency to ignore things on } \\
\text { one side of the body. }\end{array}$ & & & & & \\
\hline $\begin{array}{l}\text { 9. Apraxia of speech - a disorder of motor program- } \\
\text { ming of speech. }\end{array}$ & & & & & \\
\hline $\begin{array}{l}\text { 10. Dressing apraxia - loss of ability to put on or } \\
\text { take off clothes in an orderly manner. }\end{array}$ & & & & & \\
\hline 11. Amnesia - impairment of memory. & & & & & \\
\hline $\begin{array}{l}\text { 12. Dysarthria - impairment in the articulation of } \\
\text { sounds due to muscle weakness and incoordination } \\
\text { of muscles for speech and breathing. }\end{array}$ & & & & & \\
\hline $\begin{array}{l}\text { 13. Visual agnosia - inability to recognise objects, } \\
\text { colours, and pictures. }\end{array}$ & & & & & \\
\hline $\begin{array}{l}\text { 14. Auditory agnosia - inability to comprehend speech } \\
\text { and/or non-speech sounds in the face of normal } \\
\text { hearing. }\end{array}$ & & & & & \\
\hline $\begin{array}{l}\text { 15. Disorder of proprioception - lack of awareness of a } \\
\text { part of the body in relation to its position in space. }\end{array}$ & & & & & \\
\hline
\end{tabular}




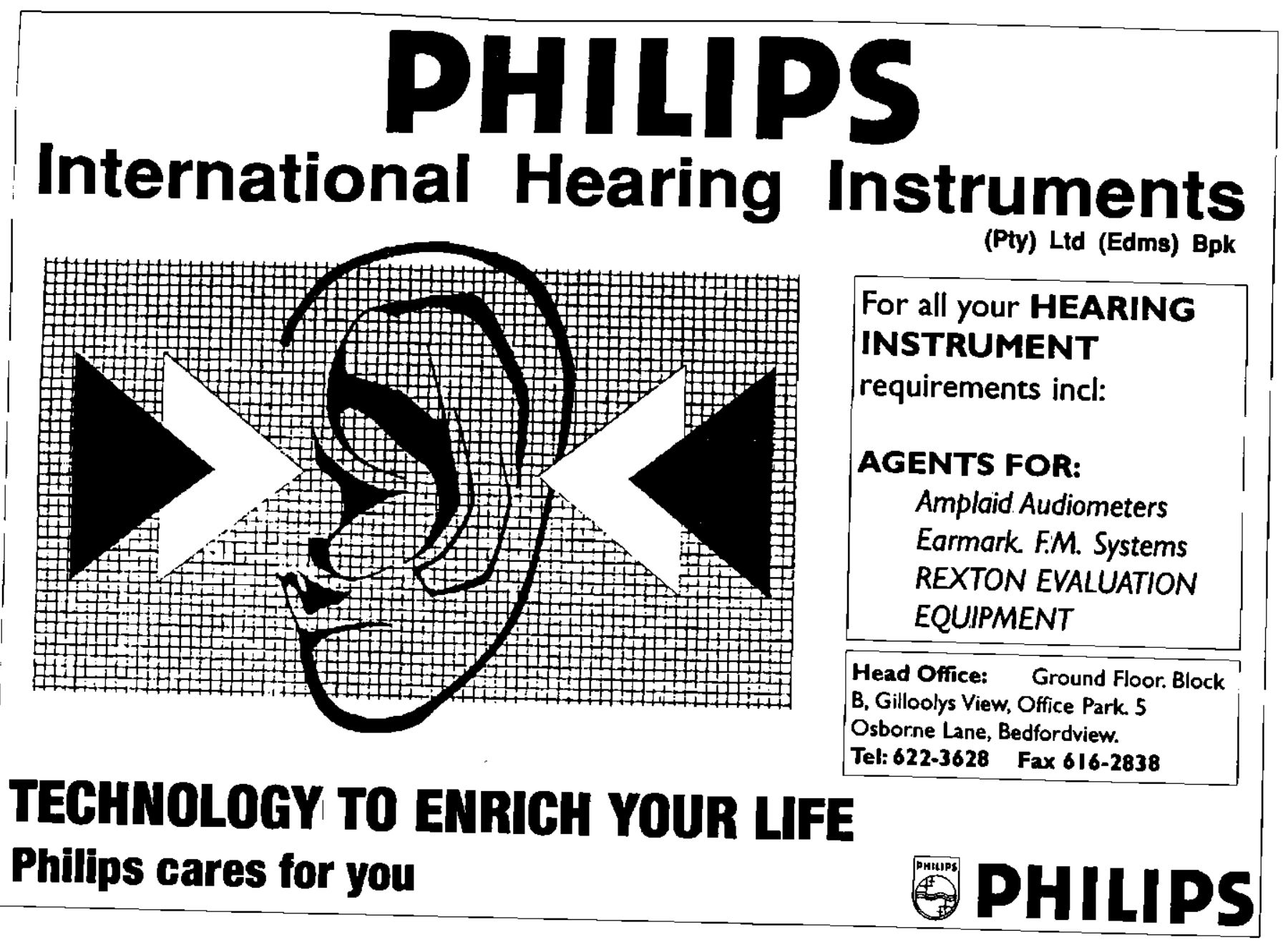

